\title{
Support and Challenges during Teaching Practicum: A Survey of B. Ed (Hons) Prospective Teachers of Public Universities of Khyber Pakhtunkhwa
}

\author{
* Mir Ahmad Shah, PhD Scholar \\ ** Dr. Syed Munir Ahmad, Associate Professor \\ *** Dr. Khisro Kaleem Raza, Head (Corresponding Author)
}

\begin{abstract}
Teaching practicum is an essential and mandatory component of any teacher education program, which is also manifested from the weightage given to it in the B.Ed. (Hons) scheme of studies. This paper explores perceptions of prospective teachers about support and challenges during teaching practicum in public universities of Khyber Pakhtunkhwa. The study also sought to explore the concerns of prospective teachers of the school environment and staff, mentoring and cooperative teachers' support, and classroom management during teaching practicum placement. Following a quantitative approach, data were collected through purposive sampling technique, using an adapted form of the Extended Practicum Learning Environment Inventory (EPELI). The study included participants from three public sector universities, namely the University of Peshawar, Islamia College University Peshawar, and Shaheed Benazir Bhutto Women University Peshawar. The findings show that prospective teachers received support from their mentors, peers, and school administration. The results also show that that prospective teachers faced various challenges during teaching practicum, which included mentor support, teaching anxiety, coping with mischievous students, lack of support from para-teaching staff at schools, and lack of involvement in school administrative matters. For improving the quality of teaching practicum at schools, proper school-college partnerships must be maintained, structures of school-based professional support are properly and professionally developed and maintained, and a deeper awareness of learner-cantered pedagogy is enacted.
\end{abstract}

Keywords: Teacher Education, Prospective Teachers Experiences, Teaching Practicum Introduction

Professional development is the cornerstone of every teacher's education system, and the quality of education is highly dependent on the teacher training program (Hicks, 2018). Teacher training institutes are responsible for improving their level of teacher preparedness to meet the 21 stcentenary challenges. Student teachers need much preparation before they join the school for teaching practicum. Training preparation provided in the institutions has a significant impact on the preparedness of student teachers for real classroom teaching.

Teaching practicum plays a critical role in the transformation process of trainee teachers to a professionally qualified teacher. It has been established that all the Pre-Service Teacher Training Programs give high priority to practical teaching (Gujjar et al., 2010).

The term teaching practicum encompasses all the learning experiences of prospective teachers during their placement in the schools. It is a preparation phase for student teachers to learn how to teach through practical means. It is integral to the professional development of trainee teachers to shape their convictions and teaching ideas. Teaching practicum is the practical use of teaching methods, tactics, principles, techniques, practical training, and application of different activities of daily school life (Azeem, 2011).

Several terms are used interchangeably for teaching practicum such as practice teaching, student teaching, teaching practice, field studies, in-field learning, school-based learning, or internship (Azeem 2011, Gujjar et al., 2011).

\footnotetext{
* IER University of Peshawar Email: mironly@yahoo.com

** IER University of Peshawar Email: mas.uon@gmail.com

*** Department of Education, Sarhad University Peshawar Email: khisro.edu@ suit.edu.pk
} 
Teaching practicum has been considered a base for student teachers' training. They practice the art of teaching in a real school environment in the classroom for a specific time to explore the school environment and the factors that affect the teaching-learning process (Tumuhe,2019). Bello \& Ayelaagbe (2015) mentioned that teaching practice is the name of the preparation of student teachers for teaching by practical training. In teaching practice, students gain first-hand real classroom teaching experience under the supervision of a trained and skilful mentor. Koross (2016) defines teaching practice as a series of exercises from which the student teachers go through in the classroom and school. Azeem (2011) defines it as the time of prospective teachers, which they spend under the supervision of a mentor teacher, for seeking teaching skills in a real classroom situation. According to Kennedy (2006), teaching practice is a practice in which a prospective teacher begins his/her teaching under the supervision of a skilful and experienced mentor and applies the learned theory into practice.

Koross (2016) reported that teaching practicum provides prospective teachers with practical experience of teaching an opportunity to put their learning theories into practice before joining the teaching profession. Teaching practicum has the leading role in the teacher education program as itis the ultimate practical experience of prospective teachers before entering the teaching profession, which provides a chance of being socialized in teaching. Practice teaching has three significant implications: the practicing of teaching skills and possession of the role of a teacher; the whole spectrum of experiences that students go through in schools; and the practical features of the course as distinct from theoretical studies. Teaching practice can be referred to all the learning experience of prospective teachers happened to them in schools (Gujjar et al., 2011).

According to Khanam (2015), teaching practicum is the specific duration of time where trainee teachers secure direct experiences of teaching. It is a chance given to prospective teachers to improve their teaching skills and prepare for future placement in a real classroom environment under the supervision of a trained teacher (Azeem, 2011).

It's unanimously considered the vital aspect of student teachers preparation by the researchers all over the world due to the real classroom and teaching-learning experiences (Parrott, 2018, Hicks, 2018, Gujjar et al., 2011, Khanam, 2015). It is recommended that a comprehensive teacher education program must possess an effective teaching practicum program. Bichi andMusa (2017) concluded that practical experiences have more effects on student experiences than bookish and textual knowledge in the classroom. Hence a teacher cannot acquire the teaching skills until and unless he experienced and throw the practical teaching experience. There is no other subject or component in a teacher training program that can fulfil students' training needs except teaching practicum (Hicks, 2018). Koross (2016) asserted that the majority of prospective teachers consider teaching practicum the most rewarding and beneficial program in terms of the learning of teaching skills and knowledge. It provides a chance for prospective teachers to strengthen their skills and become socialized into the profession.

Parrott (2018) believes that the teaching practicum and the teaching practicum's quality are a debatable issue of great concern among the stalk holder throughout the world. As an indispensable activity of the teacher education program, it is necessary to give proper attention to conducting it effectively. It is imperative to procure a degree in the teacher education program at the undergraduate level, both informal and distance education systems in Pakistan (Gujjar et al., 2010).

The practical part of teacher education possesses numerous issues that are faced by prospective teachers in the real school environment. Some of these challenges are student-teacher identity issues, unclear roles in school, anxiety, stress, the attitude of school teaching and nonteaching staff, pupil problems of behavior and classroom, workload, and lack of experience (Mtika, 2011). The study of Khan et al. (2016) found the areas of challenges during practicum; these include the limited strenuous role of mentor and cooperative teacher, lack of triad meeting, proper engagement of student teachers in administrative work, lack of seminars to address student problems, rare visits of the supervisor to schools and inappropriate evaluation and guidance of prospective teachers. Bichi and Musa (2017) noted that most prospective teachers are not satisfied with the existing teaching practicum model due to its short duration. The research also unveils that the role of the prospective teacher in the practicing school is ambiguous and unclear, due to which they cannot teach the class confidently. High expectations and lack of experience keep them always under pressure. Hamilton-Ekeke, (2017) uncovered that for practical training, teaching practice should be 
flexible in time, course content, teaching methods, and teaching, for which the current model of teaching practice is not flexible enough for prospective teachers.

Koross (2016) argued that teaching practicum influences prospective teacher's decision to choose teaching as a profession. They face various challenges like inadequate training, terrestrial distance, little and weak degree of teaching skills, non-existence of resources \& discipline, their unclear role in the school, and so on. These challenges should be overcome in making teaching practicum more advantageous and improving prospective teachers' professional capabilities.

Ali et al. (2018) argue that prospective teachers complain about a deficiency of teaching aids and laboratory facilities, which creates obstacles in subject teaching. Lack of experience and inadequate knowledge of teaching also create issues in teaching lower classes. Despite all the good and bad experiences, teaching practicum makes them confident, learned, experienced, and professionally grown teachers.

Frimpong (2016) stated that teaching institutes anticipate from prospective teachers to perform all the practices according to teacher guidance; however, for the development and improvement of the teaching practicum process and prospective teachers teaching quality, proper involvement of all the stalk holders is required. As the supervisor's role is crucial in a teaching practicum, supervisors should be assigned a limited number of students to evaluate and guide prospective teachers' lessons more effectively.

Gujjar et al. (2011) exhibit the challenges that prospective teachers experience during their practical teaching phases. These include short duration, limited opportunity for teaching all subjects, negligence of choice while assigning lessons, unequal time allocation for theory and practice, and unaccountability. Prospective teachers should be provided with an opportunity to demonstrate a lesson in various subjects to different levels of students to get sufficient experience and knowledge.

\section{Statement of Problem}

Teaching practicum in its nature is a more challenging phase for prospective teachers in the teacher education program. Its challenges have significant effects on their teaching profession. As the actual practice of teaching much depends on infield experiences, therefore, there is a need to find the solution to the challenges prospective teachers face during teaching practicum to help them transition from student teacher to in-service teacher. Several studies have been conducted on various issues of teaching practicum globally. In the Pakistani context, although the available studies related to teaching practicum are useful and vital, the current research is a step advanced towards the support and challenges faced by the prospective teachers during teaching practicum in B.Ed. (Hons), with particular reference to the public sector universities of Khyber Pakhtunkhwa, Pakistan.

\section{Significance of the Study}

The findings of the study in hand are significant in guiding placement schools, student teachers, and the institutions responsible for teacher training. It also enables the heads, teachers, mentors, and researchers to understand the strengths and weaknesses of teaching practicum, especially in B.Ed. (Hons) program. An understanding of student teachers' problems concerning teaching practicum provides insight to the stakeholders to make it beneficial and achieve the program's desired outcomes.

Besides, this study considers the support and challenges faced by the student-teachers who are directly affected by the practicum quality and the nature of guidance. Thus an insight into the issues faced by prospective teachers and recommendations for improving the teaching practicum is expected to uplift the quality of teacher education in the long run.

\section{Objectives}

The objectives of the study were to:

1. Find out the support prospective teachers get during their teaching practicum.

2. Investigate the challenges prospective teachers face during their teaching practicum.

3. Suggest measures for improving teaching practicum

\section{Research Questions}

The study was intended to answer the following questions:

1. What support prospective teachers do receive during teaching practicum?

2. Which challenges do prospective teachers face during teaching practicum?

3. How the prospective teachers' teaching practicum can be improved? 


\section{Methodology}

The study's nature was descriptive; therefore, a quantitative research approach was adopted to investigate the support and challenges faced by prospective teachers during teaching practicum.

The population of the study consisted of all the prospective teachers who are enrolled in B.Ed.

(Hons) program at the University of Peshawar, Islamia College University Peshawar, and Shaheed Benazir Bhutto Women University Peshawar.

\section{Sampling Method}

The study adopted a purposive sampling method selecting (50) student teachers from each sample university, (90) females, and (60) males, who have gone through the experiences of Teaching Practicum experiences, beyond the 3rd semester $(n=150)$.

\section{Data Collection}

The data were collected through a modified form of the self-report "Extended Practicum Learning Environment Inventory" EPLEI (Kennedy, 2006), including 30 items. The stated scale consisted of a five-point Likert Scale, including responses strongly agree, agree, undecided, disagree, and strongly disagree. The researcher personally administered the tool.

\section{Data and their Analyses}

The collected data was arranged, tabulated, and subjected to the Chi-Square test and standard deviation. The summary is provided in the following tables:

Table 1: Prospective teachers support during teaching practicum

\begin{tabular}{|c|c|c|c|c|c|c|c|c|c|}
\hline $\begin{array}{c}\text { A } \\
\text { S.No }\end{array}$ & Personal support & $S A$ & $A$ & $N$ & $\bar{D}$ & SDA & $\begin{array}{l}x^{2} \\
\text { P- } \\
\text { Value }\end{array}$ & $\overline{\text { Df }}$ & Remarks \\
\hline 1 & Theory and practice & 73 & 35 & 28 & 12 & 02 & 45.307 & 4 & Agreed \\
\hline & & $48.7 \%$ & $23.3 \%$ & $18.7 \%$ & $8 \%$ & $1.3 \%$ & 0.000 & & \\
\hline 2 & $\begin{array}{l}\text { Develop } \\
\text { confidence }\end{array} \quad$ self- & $\begin{array}{l}78 \\
52 \%\end{array}$ & $\begin{array}{l}36 \\
24 \%\end{array}$ & $\begin{array}{l}14 \\
9.3 \%\end{array}$ & $\begin{array}{l}12 \\
8 \%\end{array}$ & $\begin{array}{l}10 \\
6.6 \%\end{array}$ & $\begin{array}{l}110.667 \\
0.000\end{array}$ & 4 & Agreed \\
\hline 3 & pedagogical skills & $\begin{array}{l}53 \\
35.3 \%\end{array}$ & $\begin{array}{l}32 \\
21.3 \%\end{array}$ & $\begin{array}{l}25 \\
16.7 \%\end{array}$ & $\begin{array}{l}27 \\
18 \%\end{array}$ & $\begin{array}{l}13 \\
8.7 \%\end{array}$ & $\begin{array}{l}28.533 \\
0.000\end{array}$ & 4 & Agreed \\
\hline 4 & Relationship & $\begin{array}{l}29 \\
19.3 \%\end{array}$ & $\begin{array}{l}31 \\
20.7 \%\end{array}$ & $\begin{array}{l}40 \\
26.7 \%\end{array}$ & $\begin{array}{l}35 \\
23.3 \%\end{array}$ & $\begin{array}{l}15 \\
10 \%\end{array}$ & $\begin{array}{l}11.733 \\
0.000\end{array}$ & 4 & Agreed \\
\hline 5 & Seminar & $\begin{array}{l}2 \\
1.3 \%\end{array}$ & $\begin{array}{l}1 \\
.7 \%\end{array}$ & $\begin{array}{l}19 \\
12.7 \%\end{array}$ & $\begin{array}{l}55 \\
36.7 \%\end{array}$ & $\begin{array}{l}73 \\
48.7 \%\end{array}$ & $\begin{array}{l}140.667 \\
0.000\end{array}$ & 4 & Disagreed \\
\hline 6 & Attend Triad Meeting & $\begin{array}{l}19 \\
12.7 \%\end{array}$ & $\begin{array}{l}47 \\
31.3 \%\end{array}$ & $\begin{array}{l}27 \\
18 \%\end{array}$ & $\begin{array}{l}44 \\
29.3 \%\end{array}$ & $\begin{array}{l}13 \\
8.7 \%\end{array}$ & $\begin{array}{l}19 \\
12.7 \%\end{array}$ & $\begin{array}{l}47 \\
31.3 \%\end{array}$ & Agreed \\
\hline B & Personnel support & & & & & & & & \\
\hline 1 & School teaching staff & $\begin{array}{l}11 \\
7.3 \%\end{array}$ & $\begin{array}{l}30 \\
20 \%\end{array}$ & $\begin{array}{l}40 \\
26.7 \%\end{array}$ & $\begin{array}{l}59 \\
39.3 \%\end{array}$ & $\begin{array}{l}10 \\
6.7 \%\end{array}$ & $\begin{array}{l}60.067 \\
0.000\end{array}$ & 4 & Disagreed \\
\hline 2 & Mentor teacher & $\begin{array}{l}52 \\
34.6 \%\end{array}$ & $\begin{array}{l}38 \\
25.3 \%\end{array}$ & $\begin{array}{l}26 \\
17.3 \%\end{array}$ & $\begin{array}{l}23 \\
15.3 \%\end{array}$ & 00 & $\begin{array}{l}32.467 \\
0.000\end{array}$ & 4 & Agreed \\
\hline 3 & cooperative teacher & $\begin{array}{l}53 \\
35.3 \%\end{array}$ & $\begin{array}{l}32 \\
21.3 \%\end{array}$ & $\begin{array}{l}25 \\
16.7 \%\end{array}$ & $\begin{array}{l}27 \\
18 \%\end{array}$ & $\begin{array}{l}13 \\
8.7 \%\end{array}$ & $\begin{array}{l}28.533 \\
0.000\end{array}$ & 4 & Agreed \\
\hline 4 & Peer & $\begin{array}{l}71 \\
47.3 \%\end{array}$ & $\begin{array}{l}46 \\
30.7 \%\end{array}$ & $\begin{array}{l}17 \\
11.3 \%\end{array}$ & $\begin{array}{l}10 \\
6.6 \%\end{array}$ & $\begin{array}{l}06 \\
04 \%\end{array}$ & $\begin{array}{l}55.387 \\
0.000\end{array}$ & 3 & Agreed \\
\hline 5 & Pupils & $\begin{array}{l}34 \\
22.7 \%\end{array}$ & $\begin{array}{l}54 \\
36 \%\end{array}$ & $\begin{array}{l}28 \\
18.7 \%\end{array}$ & $\begin{array}{l}27 \\
18 \%\end{array}$ & $\begin{array}{l}7 \\
4.7 \%\end{array}$ & $\begin{array}{l}37.800 \\
0.000\end{array}$ & 4 & Agreed \\
\hline 6 & $\begin{array}{l}\text { Principal and } \\
\text { administration }\end{array}$ & $\begin{array}{l}9 \\
6 \%\end{array}$ & $\begin{array}{l}39 \\
26 \%\end{array}$ & $\begin{array}{l}47 \\
31.3 \%\end{array}$ & $\begin{array}{l}47 \\
31.3 \%\end{array}$ & $\begin{array}{l}8 \\
5.3 \%\end{array}$ & $\begin{array}{l}52.800 \\
0.000\end{array}$ & 4 & Disagreed \\
\hline $\mathrm{C}$ & $\begin{array}{l}\text { Environmental } \\
\text { support }\end{array}$ & & & & & & & & \\
\hline 1 & Classroom seating & $\begin{array}{l}17 \\
11.3 \%\end{array}$ & $\begin{array}{l}54 \\
36 \%\end{array}$ & $\begin{array}{l}35 \\
23.3 \%\end{array}$ & $\begin{array}{l}27 \\
18 \%\end{array}$ & $\begin{array}{l}17 \\
11.3 \%\end{array}$ & $\begin{array}{l}31.600 \\
0.000\end{array}$ & 4 & Agreed \\
\hline 2 & $\begin{array}{l}\text { Facilities and } \\
\text { Resources }\end{array}$ & $\begin{array}{l}8 \\
5.3 \%\end{array}$ & $\begin{array}{l}25 \\
16.7 \%\end{array}$ & $\begin{array}{l}44 \\
29.3 \%\end{array}$ & $\begin{array}{l}35 \\
23.3 \%\end{array}$ & $\begin{array}{l}38 \\
25.3 \%\end{array}$ & $\begin{array}{l}26.467 \\
0.000\end{array}$ & 4 & Disagreed \\
\hline 3 & Work load & $\begin{array}{l}38 \\
25.3 \%\end{array}$ & $\begin{array}{l}40 \\
26.6 \%\end{array}$ & $\begin{array}{l}21 \\
14 \%\end{array}$ & $\begin{array}{l}46 \\
30.6 \%\end{array}$ & $\begin{array}{l}5 \\
3.3 \%\end{array}$ & $\begin{array}{l}37.533 \\
0.000\end{array}$ & & Agreed \\
\hline 4 & $\begin{array}{l}\text { Involvement in the } \\
\text { school decision- } \\
\text { making process }\end{array}$ & $\begin{array}{l}1 \\
0.6 \%\end{array}$ & $\begin{array}{l}26 \\
17.3 \%\end{array}$ & $\begin{array}{l}23 \\
15.3 \%\end{array}$ & $\begin{array}{l}79 \\
52.6 \%\end{array}$ & $\begin{array}{l}21 \\
14 \%\end{array}$ & $\begin{array}{l}112.933 \\
0.000\end{array}$ & 4 & Disagreed \\
\hline
\end{tabular}




\begin{tabular}{lllllllllll}
\hline $\mathbf{5}$ & Library & and & 12 & 31 & 31 & 44 & 32 & 18.467 & 4 & Disagreed \\
& laboratory & & $8 \%$ & $20.7 \%$ & $20.7 \%$ & $29.3 \%$ & $21.3 \%$ & & & \\
$\mathbf{6}$ & Internet & and & 8 & 25 & 44 & 35 & 38 & 26.467 & & Disagreed \\
& technology & & $5.3 \%$ & $16.7 \%$ & $29.3 \%$ & $23.3 \%$ & $25.3 \%$ & & & \\
\hline
\end{tabular}

$1_{\text {Note. }} \mathrm{SA}=$ Strongly Agree, A=Agree, UD=Undecided, DA=Disagree, SDA=Strongly Disagree $\mathrm{N}=150$

Table 1 manifests prospective teachers' support during teaching practicum, which is further classified into personal, personnel, and environmental support. It is evident from the table that $72 \%$ of the student teacher-developed their connection of theoretical and practical knowledge, while $76 \%$ enhanced their self-confidence during teaching practicum. 56.6\% of the respondent developed their pedagogical skills, $40 \%$ affirmed the right rapport with pupils and staff members of the school. It is found that $44 \%$ of the respondent did not involve in triad meetings with mentor and cooperative teachers, while $86 \%$ did not attend any seminar to address their issues.

Prospective teachers got different personnel support during the practicum phase. $27.3 \%$ respondent acknowledged the support of teaching staff, while nearly $60 \%$ were authenticated mentor support during their practicum stage. Cooperative teachers supported $56.6 \%$ of student teachers, peer support was confirmed by $78 \%$ of the respondents.41.6\% of the respondents were in the view that pupils in the class support them, while $32 \%$ of the respondent got support from school principal and administration.

Trainee teachers were supported in many ways in the placement school. $47.3 \%$ found classroom furniture and management satisfactory for teaching-learning, while only $22 \%$ were satisfied with school facilities and teaching-learning resources. Nearly $52 \%$ of the student teachers experienced a heavy workload. Only $17 \%$ of the student teachers were involved in the school decision-making process. The facilities of library and laboratory and availability of internet and modern technologies were provided to only $28.7 \%$ and $22 \%$ student teachers sequentially.

Table2: Prospective teachers challenges during teaching practicum

\begin{tabular}{|c|c|c|c|c|c|c|c|c|c|}
\hline $\begin{array}{c}\text { A } \\
\text { S.No }\end{array}$ & Personal challenges & $S A$ & $\bar{A}$ & $N$ & $D$ & $S D A$ & $\begin{array}{c}x^{2} \\
\text { P-Value }\end{array}$ & $\overline{\text { Df }}$ & Remarks \\
\hline 1 & Financial issues & $\begin{array}{l}119 \\
79 \%\end{array}$ & $\begin{array}{l}18 \\
12 \%\end{array}$ & $\begin{array}{l}9 \\
6 \%\end{array}$ & $\begin{array}{l}4 \\
3 \%\end{array}$ & 00 & $\begin{array}{l}238.853 \\
0.000\end{array}$ & 3 & Agreed \\
\hline 2 & Teaching Anxiety & $\begin{array}{l}45 \\
30 \%\end{array}$ & $\begin{array}{l}48 \\
32 \%\end{array}$ & $\begin{array}{l}19 \\
12.3 \%\end{array}$ & $\begin{array}{l}21 \\
14 \%\end{array}$ & $\begin{array}{l}17 \\
11.3 \%\end{array}$ & $\begin{array}{l}30.667 \\
0.000\end{array}$ & 4 & Agreed \\
\hline 3 & $\begin{array}{l}\text { developing } \\
\text { administrative skills }\end{array}$ & $\begin{array}{l}1 \\
0.6 \%\end{array}$ & $\begin{array}{l}40 \\
26.6 \%\end{array}$ & $\begin{array}{l}3 \\
2 \%\end{array}$ & $\begin{array}{l}90 \\
60 \%\end{array}$ & $\begin{array}{l}16 \\
10.6 \%\end{array}$ & $\begin{array}{l}192.560 \\
0.000\end{array}$ & 3 & Disagreed \\
\hline 4 & Identity issue & $\begin{array}{l}50 \\
33.3 \%\end{array}$ & $\begin{array}{l}47 \\
31.3 \%\end{array}$ & $\begin{array}{l}17 \\
11.3 \%\end{array}$ & $\begin{array}{l}20 \\
13.3 \%\end{array}$ & $\begin{array}{l}16 \\
10.6 \%\end{array}$ & $\begin{array}{l}38.467 \\
0.000\end{array}$ & 4 & Agreed \\
\hline 5 & $\begin{array}{l}\text { planning teaching } \\
\text { strategies }\end{array}$ & $\begin{array}{l}10 \\
6.6 \%\end{array}$ & $\begin{array}{l}32 \\
21.3 \%\end{array}$ & $\begin{array}{l}1 \\
0.6 \%\end{array}$ & $\begin{array}{l}99 \\
66 \%\end{array}$ & $\begin{array}{l}08 \\
5.3 \%\end{array}$ & $\begin{array}{l}114.280 \\
0.000\end{array}$ & 2 & Disagree \\
\hline 6 & Length of practicum & $\begin{array}{l}20 \\
13.3 \%\end{array}$ & $\begin{array}{l}39 \\
26.0 \%\end{array}$ & $\begin{array}{l}47 \\
31.3 \%\end{array}$ & $\begin{array}{l}38 \\
25.3 \%\end{array}$ & $\begin{array}{l}6 \\
4 \%\end{array}$ & 37.000 & & Agreed \\
\hline B & Personnel challenges & & & & & & & & \\
\hline 1 & Behavior problems & $\begin{array}{l}48 \\
32 \%\end{array}$ & $\begin{array}{l}46 \\
30.6 \%\end{array}$ & $\begin{array}{l}26 \\
17.3 \%\end{array}$ & $\begin{array}{l}20 \\
13.3 \%\end{array}$ & $\begin{array}{l}10 \\
6.6 \%\end{array}$ & $\begin{array}{l}36.533 \\
0.000\end{array}$ & 4 & Agreed \\
\hline 2 & $\begin{array}{l}\text { Disciplining the } \\
\text { problematic pupils }\end{array}$ & $\begin{array}{l}38 \\
25.3 \%\end{array}$ & $\begin{array}{l}40 \\
26.6 \%\end{array}$ & $\begin{array}{l}21 \\
14 \%\end{array}$ & $\begin{array}{l}46 \\
30.6 \%\end{array}$ & $\begin{array}{l}5 \\
3.3 \%\end{array}$ & $\begin{array}{l}37.533 \\
0.000\end{array}$ & 4 & Agreed \\
\hline 3 & $\begin{array}{l}\text { Cooperative teacher } \\
\text { feedback }\end{array}$ & $\begin{array}{l}35 \\
23.3 \%\end{array}$ & $\begin{array}{l}46 \\
30.7 \%\end{array}$ & $\begin{array}{l}25 \\
16.7 \%\end{array}$ & $\begin{array}{l}38 \\
25.3 \%\end{array}$ & $\begin{array}{l}6 \\
4 \%\end{array}$ & $\begin{array}{l}31.533 \\
0.000\end{array}$ & 4 & Agreed \\
\hline 4 & $\begin{array}{l}\text { placement school } \\
\text { teaching staff }\end{array}$ & $\begin{array}{l}39 \\
26 \%\end{array}$ & $\begin{array}{l}48 \\
32 \%\end{array}$ & $\begin{array}{l}13 \\
8.7 \%\end{array}$ & $\begin{array}{l}25 \\
16.7 \%\end{array}$ & $\begin{array}{l}25 \\
16.7 \%\end{array}$ & $\begin{array}{l}24.800 \\
0.000\end{array}$ & 4 & Agreed \\
\hline 5 & $\begin{array}{l}\text { Engaged in relief } \\
\text { teaching by school } \\
\text { teachers }\end{array}$ & $\begin{array}{l}89 \\
59.3 \%\end{array}$ & $\begin{array}{l}38 \\
25.3 \%\end{array}$ & $\begin{array}{l}9 \\
6 \%\end{array}$ & $\begin{array}{l}5 \\
3.3 \%\end{array}$ & $\begin{array}{l}9 \\
6 \%\end{array}$ & $\begin{array}{l}168.400 \\
0.000\end{array}$ & 4 & Agreed \\
\hline 6 & $\begin{array}{l}\text { Parental involvement } \\
\text { Classroom challenges }\end{array}$ & $\begin{array}{l}119 \\
79.3 \%\end{array}$ & $\begin{array}{l}18 \\
12.0 \%\end{array}$ & $\begin{array}{l}9 \\
6 \%\end{array}$ & $\begin{array}{l}4 \\
2.7 \%\end{array}$ & 00 & 238.853 & 3 & Agreed \\
\hline
\end{tabular}




\begin{tabular}{|c|c|c|c|c|c|c|c|c|c|}
\hline \multirow[t]{2}{*}{1} & Class room & 37 & 51 & 40 & 20 & 2 & 49.133 & 4 & Agreed \\
\hline & management & $24.6 \%$ & $34 \%$ & $26.6 \%$ & $13.3 \%$ & $1.3 \%$ & 0.000 & & \\
\hline \multirow[t]{2}{*}{2} & Effective classroom & 41 & 54 & 21 & 34 & & 15.173 & 3 & Agreed \\
\hline & interaction & $27.3 \%$ & $36 \%$ & $14 \%$ & $22.6 \%$ & & 0.000 & & \\
\hline \multirow[t]{2}{*}{3} & methods of teaching & 11 & 29 & 28 & 77 & 5 & 106.667 & 4 & Disagreed \\
\hline & & $7.3 \%$ & $19.3 \%$ & $18.6 \%$ & $51.3 \%$ & $3.3 \%$ & 0.000 & & \\
\hline \multirow[t]{2}{*}{4} & Syllabus completion & 11 & 30 & 40 & 59 & 10 & 56.733 & 4 & Disagreed \\
\hline & & $7.3 \%$ & $20 \%$ & $26.7 \%$ & $39.3 \%$ & $6.7 \%$ & 0.000 & & \\
\hline \multirow[t]{2}{*}{5} & time table challenges & 65 & 17 & 21 & 39 & 8 & 68 & 4 & Agreed \\
\hline & & $43.3 \%$ & $11.3 \%$ & $14 \%$ & $26 \%$ & $5.3 \%$ & 0.000 & & \\
\hline \multirow[t]{2}{*}{6} & Lesson planning & 17 & 54 & 35 & 27 & 17 & 31.600 & 4 & \\
\hline & & $11.3 \%$ & $36 \%$ & $23.3 \%$ & $18 \%$ & $11.3 \%$ & & & \\
\hline
\end{tabular}

${ }^{1}$ Note.SA=Strongly Agree, A=Agree, UD=Undecided, DA=Disagree, SDA=Strongly Disagree $\mathrm{N}=250$

Table 2 unveils the challenges prospective teachers faced during teaching practicum, which is further divided into personal personnel and classroom challenges. It is evident from the table that most of the respondents, $91 \%$ faced different financial issues during the internship stage. $62 \%$ of the respondents experienced anxiety challenges, while nearly $46 \%$ had faced identity issues. Developing administrative skills and planning teaching strategies were remained a challenge for almost $64 \%$ and $52 \%$ respectively. $39.3 \%$ found the length of practicum inadequate.

Nearly $63 \%$ of the prospective teachers faced behavior problems while $28 \%$ found challenging to disciplined problematic pupils. $54 \%$ of the student teachers found cooperative teacher feedback challenging to adopt. 58\% of the trainee teachers experienced challenges from school teaching staff, while nearly $85 \%$ admitted engagement in relief teaching a challenging task. $91.3 \%$ of student teachers found pupils parents involvement a challenging task.

Classroom management and effective communication and interaction were remaining challenging for 58 and $63 \%$ respectively. Nearly $27 \%$ found challenging practicing different teaching methods, while $27 \%$ found syllabus completion a challenging task.

About $55 \%$ of the respondents faced challenges in the time table, and $47.3 \%$ in lesson planning.

\section{Findings}

The following findings were recorded from the analysis of data:

- The majority of the students $(72 \%)$ were supported to develop their connection of theory with practical knowledge.

- Most of the student teachers (72\%) enhanced their self-confidence, while nearly 57\% were encouraged to develop their teaching skills.

- $\quad$ The majority of the student teachers did not attend any seminars (86\%).

- Mentor support was acknowledged by $60 \%$ of the respondents, while $78 \%$ revealed peer support during teaching practicum.

- Nearly half of the respondents respond to the lack of facilities and resources in the placement school, while more than half of the student teachers complained about the workload.

- $\quad 66 \%$ of the respondents were not involved in the school policymaking process.

- More than half of the student teachers had no access to the library and laboratory (50.6\%), while $48.6 \%$ of the respondents found challenging the availability of internet and technology like projectors and laptops.

- The financial issue was among one of the challenges faced by most of the student-teacher (91\%), while (62\%) met teaching anxieties.

- Developing administrative skills and teaching strategies were experienced by $64 \%$ and $52 \%$. Most of the respondents, $63 \%$ faced pupil's behavior problems, while more than half of the respondents (54\%) found adopting cooperative teacher's feedback and suggestion a challenging task.

- $\quad$ Parental involvement in the school environment was found a challenging task by $(91.3 \%)$ of the student teachers.

- $\quad$ Non-cooperative behavior of school teacher and participation of prospective teachers in relief teaching was recorded by $(58 \%)$ and $(85 \%)$ of the respondents. 
- $\quad$ Classroom management (58\%) and effective communication (63\%) remained a challenging task while practicing different teaching methods were found challenging by nearly $(55 \%)$ of the respondent.

\section{Discussion}

The current study was in coherence with several studies already conducted over the support received by prospective teachers, such as student teachers found a lack of support from the placement school environment and non-teaching staff (Koross, 2016, Saifi, 2013, and Gujjar et al., 2010).

Similarly, Mentor teacher support, feedback, and evaluation (Capello, 2020, Selçuk, \&Yöntem, 2019, Ali, Othman, \& Karim, 2018) help prospective teachers to enhance their skills during teaching practicum. The same findings were received through the given study, which supports the stated idea.

The study revealed that pedagogical skills and prospective teacher's experiences are important for quality teaching. The same results have been reported by Mtika (2011) and Gujjar et al. (2010).

The majority of student teachers acknowledged cooperative teacher support, whereas the findings of Saifi (2013), Selçuk, \&Yöntem (2019) presented the same results.

The findings of this study also support the result of previous studies which have shown that prospective teachers face numerous issues and challenges during teaching practicum (Selçuk, \&Yöntem 2019, Koşar \& Bedir, 2019, Ali et al., 2018, Mosaddaq, 2016).

Teaching anxiety causes a lack of experience, classroom management, and teaching skills on the part of student teachers. Reports of studies conducted by Selçuk and Yöntem (2019), Glavačević (2018), Mosaddaq (2016) Eksi and Yakisik (2016), Mtika (2011), Koşar and Bedir (2019), and Koross (2016) presented that various sources of teaching practicum anxieties operate during their experiences.

Student behavior\& making problematic pupils disciplined was another issue for most of the student teachers. Selçuk and Yöntem (2019), Ali et al. (2018), Koross (2016), Koşar and Bedir (2019) shows the similar results that the majority of student teachers were concerned over the student discipline and misbehavior, lack of interest in learning, bullying, and teasing each other, as well as teachers and non-serious attitude, are some of the issues that student teachers experience during their teaching practicum.

Interaction and communication with the pupil is also a challenging issue for student teachers. (Selçuk, \&Yöntem, 2019, Saifi, 2013) found communication and interaction gaps and problems with pupils. Passing and picking messages intentionally or unintentionally are not easy for student teachers. Exercising different teaching methodologies (Gujjar et al., 2010) and identity issues (Koşar \& Bedir, 2019) were also supported by the current study.

\section{Recommendations}

Based on the findings of the study, the following recommendations were presented:

1. Prospective teachers should be properly trained in the coursework period in lesson planning and teaching methodologies.

2. The length of the teaching practicum should be extended, and the student should be provided with support to handle their anxiety.

3. They should be provided training and mentoring in maintaining classroom discipline and resolving situations arising out of the behavioral problems of students

4. Student teachers should be providing an opportunity to practice various teaching methodologies in the classroom.

5. Timetable should be arranged according to the requirements of prospective teachers.

6. Prospective teachers should be involved in administration tasks to enhance their administrative skills.

7. The non-teaching staff of the school should be trained to extend their support towards prospective teachers.

8. Seminars and workshops should be arranged for clarifying and solving student teachers' teaching and professional development issues, concerns, and problems.

9. The student teachers should be providing teaching-learning facilities and resources.

10. A regular triad meeting should be arranged between mentor, cooperative teacher, and studentteacher. 


\section{References}

Ali, M. S., Othman, A. J., \&Karim, A. F. A. (2018). Issues and concerns faced by undergraduate language student teachers during teaching practicum experiences. MOJES: Malaysian Online Journal of Educational Sciences, 2(3), 22-30.

Azeem, M. (2011).Problems of Prospective Teachers during Teaching Practice. Academic Research International, 1(2), 308-316.

Bello, A. O., \&Ayelaagbe, S. O. (2015).Microteaching: A Strategy for Training Quality Teachers in Nigerian Colleges of Education. Journal of Qualitative Education, 11(1), 1-8.

Bichi, A. A., \& Musa, A. (2017). Evaluating the Effectiveness of Teaching Practice: Experience of Northwest University, Kano-Nigeria. International Journal for Social Studies, 3(1), 104-112.

Capello, S. (2020).Tensions in the Preparation of University Supervisors: Dual Perspectives from Supervisors and Administrators. Journal of Educational Supervision, 3(1), 18.

Eksi, G. Y., \& Yakisik, B. Y. (2016). To Be Anxious or Not: Student Teachers in the Practicum. Universal Journal of Educational Research, 4(6), 1332-1339.

Frimpong, F. (2016). Supervision of Teaching Practice as Experienced by Students, Teachers, and College Tutors: the case of Offinso College of Education, Ghana (Doctoral dissertation).

Glavačević, A. (2018). Novice teachers' strategies in overcoming classroom management anxiety (Doctoral dissertation).

Gujjar, A. A., Naoreen, B., Saifi, S., \&Bajwa, M. J. (2010).Teaching Practice: Problems and Issues in Pakistan. International Online Journal of Educational Sciences, 2(2), 339-361.

Gujjar, A. A., Ramzan, M., \&Bajwa, M. J. (2011).An Evaluation of Teaching Practice: Practicum. Pakistan Journal of Commerce and Social Sciences, 5(2), 302-318.

Hamilton-Ekeke, J. (2017). Evaluation of Teaching Practice Exercise in Nigeria. European Journal of Education Studies 2(12), 156-164.

Hicks, S. (2018). The Story of Relationship: A Narrative Inquiry into Mentor Teacher Perceptions of Their Mentoring Experiences with Teaching Candidates (Doctoral dissertation, Northwest Nazarene University).

Kennedy, J. (2006). A study of the learning environment in the extended practicum of a pre-service teacher education course at a Catholic University (Doctoral thesis, Australian Catholic University).

Khan, F., Hussain, L., \& Khan, I. (2016).Effectiveness of Practicum Component of Associate Degree in Education Programme Offered by Teacher Training Institutions in KP and Fata. Gomal University Journal of Research [GUJR], 32(2), 161-169.

Khanam, A. (2015). A practicum solution through reflection: An iterative approach. Reflective Practice, 16(5), 688-699.

Koross, R. (2016). The Student Teachers Experiences during Teaching Practice and its Impact on their Perception of the Teaching Profession.IRA International Journal of Education and Multidisciplinary Studies, 5(2), 76-85.

Koşar, G. \&Bedir, H. (2019).A comprehensive evaluation of practicum experience: From the view of preservice EFL teachers. International Online Journal of Education and Teaching (IOJET), 6(4).1001-1016.

Mosaddaq, Y. B. (2016). A Study of Sources of EFL Student Teachers 'anxiety During Their Practicum Experience. European Journal of Research and Reflection in Educational Sciences Vol, 4(1).

Mtika, P. (2011). Trainee teachers' experiences of teaching practicum: Issues, challenges, and new possibilities. Africa Education Review, 8(3), 551-567.

Parrott, A. E. (2018). Comparison of Teacher Candidates' Self-Efficacy in Traditional and Professional Development School Student Teaching Experiences (Doctoral dissertation, Concordia University Chicago).

Saifi, S. (2013).Effect of Reformed Teaching Practicum on Professional Development of B. Ed (Hons) Prospective Teachers. Bulletin of Education and Research, 35(2), 125-138.

Tumuhe, C. (2019). Assessing the Impact of the African Rural University Students' Village Practicum for 2018/19 Cohort.

Selçuk, M., \&Yöntem, E. G. (2019). Beyond Practicum: Interplay between Prospective EFL Teachers' Conceptualizations of Field Experience and Teaching Career. Advances in Language and Literary Studies, 10(1), 154-162. 